\title{
Evolution of Sequence Divergence among Human Immunodeficiency Virus Type 1 Isolates Derived from a Blood Donor and a Recipient
}

\author{
TERRY MCNEARNEY, ZUZANA HORNICKOVA, BRUCE KLOSTER, ${ }^{1}$ ANAHID BIRDWELL, \\ GREGORY A. STORCH, STEPHEN H. POLMAR, ${ }^{2}$ MAX ARENS, AND LEE RATNER \\ Departments of Medicine [T.M., Z.H., A.B., L.R.], Pathology [B.K.], Pediatrics [G.A.S., S.H.P., M.A.], and \\ Molecular Microbiology [G.A.S., S.H.P., L.R.], Washington University School of Medicine, \\ St. Louis, Missouri 63110
}

\begin{abstract}
Four neonates who were infected with a single unit of blood from a human immunodeficiency virus1 (HIV-1)-infected adult (patient 1) were studied. Two of the infected children (patients II and III) developed symptomatic HIV-1 disease and died within the first $3 \mathrm{y}$ of life. One child (patient IV) died at $8 \mathrm{mo}$ of age of clinical problems that may have been HIV-related. In contrast, one child (patient $V$ ) has remained asymptomatic for $7.5 \mathrm{y}$ and has exhibited a very gradual decline in CD4+ cell number. A previous study had shown very limited sequence diversity of isolates from patients I, II, and III (McNearney T et al.: Proc Natl Acad Sci USA 87:1917-1921, 1990). The current study examined additional HIV-1 sequences encoding the principal neutralizing V3 loop of the surface envelope protein of isolates from patients I and V. Amplified sequences were obtained using the polymerase chain reaction from a cultured isolate and uncultured peripheral blood leukocytes, and nucleotide sequences were determined for 13 clones from patient $I$ and 19 clones from patient $V$. Clones derived from the cultured isolate exhibited less predicted amino acid sequence diversity on average $(0-5.2 \%)$ than did sequences from uncultured leukocytes (0-19.8\% differences). All clones were more closely related to those from patients II and III (0-19.8\% amino acid differences) than to other North American or European isolates (18.8-27.0\% amino acid differences) or African isolates (41.0-48.0\% amino acid differences). Substitutions occurred at sites predicted to modulate host cell tropism and proteolytic cleavage of the V3 loop. Late time-point isolates from uncultivated leukocytes diverged by $6.3-$ $\mathbf{1 9 . 8 \%}$ from earlier time-point isolates or from those isolates derived from cultured leukocytes. Half of the amino acid positions at which differences occurred between earlier and late time-point HIV-1 strains were shared in isolates from patients $I$ and $V$. This demonstrates that nonrandom mutations occur in the evolution of HIV-1 genotypes during natural infection. (Pediatr Res 33: 36-42, 1993)
\end{abstract}

\section{Abbreviations}

\section{HIV, human immunodeficiency virus}

\section{Received February 6, 1992; accepted September 2, 1992.}

Correspondence: Lee Ratner, M.D., Ph.D., Box 8125, 660 South Euclid, Washington University, St. Louis, MO 63110.

T.M. is supported by National Institutes of Health Grants Al24745, AI25903, and RR-00036 and Physician Scientist Investigator Award K11 A100972. L.R. is supported by U.S. Army Medical Research Acquisition Activity contract DAMD90C-0057 and the American Cancer Society Research Professor Award.

${ }^{1}$ Current address: St. Paul American Red Cross, St. Paul, MN 55107.

${ }^{2}$ Current address: Division of Immunology, Children's Hospital, 300 Longwood Ave., Boston, MA 02115.
PBMC, peripheral blood mononuclear cells PCR, polymerase chain amplification

Retroviruses, including HIV-1 exhibit a high level of sequence variation attributed to their error-prone reverse transcriptase, recombination, and limited correction mechanisms $(1,2)$. Distinct HIV-1 strains may exhibit up to $30 \%$ nucleotide differences (3). HIV-1 isolates obtained from the same individual at different times or different tissues manifest significantly fewer differences in sequence $(1,4)$. Potential influences on the range of HIV sequence diversity include the stage of HIV-1 infection, the virus load, the level of expression of individual viral antigens, and the ensuing host immune response to viral antigens.

Sequences encoding the surface envelope protein, SU or gp 120, have the highest level of sequence changes in the HIV-1 genome $(5,6)$. Within gp 120 , amino acid changes tend to cluster in five distinct "variable" or "V" regions (7). Several of these V regions are demarcated within disulfide-bonded cysteine loops (8). Regions V1, V2, and V3 have been implicated in virus uptake after binding to the receptor (9). In particular, a number of mutations in the V3 loop have been shown to perturb fusion between virus and the host cell independent of CD4 binding $(10,11)$. Proteolytic cleavage of the V3 loop has been demonstrated in the presence of cell surface proteases, and it is postulated to be critical to the virus infection process $(12-15)$.

The V3 region has been characterized as a primary target for type-specific neutralizing antibodies recognizing a linear epitope (16). A primary determinant for cytotoxic T-cell responses has also been mapped in the V3 loop (17-19).

In a previous study, we examined sequence diversity within the envelope gene of isolates obtained from three individuals involved in a clustered infectious outbreak resulting from accidental transfusion of HIV-1-contaminated blood into two infants (1). The two pediatric patients became severely symptomatic within the 1st y of life and died of AIDS before the age of 3 y. Surprisingly, very few sequence differences $(0.02 \%)$ were identified in the env gene of HIV-1 isolates from each of these individuals. A third child received a portion of the same unit of blood and died within the 1st y of life of complications most likely related to HIV-1 infection. A fourth child was similarly infected by the same unit of blood but has remained asymptomatic for more than $7 \mathrm{y}$. The donor has recurring oral hairy leukoplakia but otherwise is also asymptomatic. The current study focuses on the evolving HIV-1 sequences from the immunodominant V3 domain obtained from this asymptomatic individual in comparison with those from the symptomatic patients and the blood donor. 


\section{SUBJECTS AND METHODS}

Case reports. Patient I is a 26-y-old homosexual male who was found to be HIV-1 seropositive 2 mo after donation of blood used for transfusion of the six pediatric patients when the HIV1 serologic assay became available. He was asymptomatic for 3.4 $y$ when he presented with oral hairy leukoplakia. He was started on azidothymidine therapy $5 \mathrm{y}$ after diagnosis of HIV infection and has otherwise remained asymptomatic. CD4 counts of this patient have remained stable between 300 and $500 / \mathrm{mm}^{2}$.

Patient II, a female, was the product of a 30 -wk gestation whose neonatal course was complicated by moderate-to-severe hyaline membrane disease with pneumothoraces, hyperbilirubinemia, apnea, bradycardia, intraventricular hemorrhage with subsequent hydrocephalus, and anemia requiring transfusion. At 8 mo of age, she was failing to thrive and suffered from persistent oral and perineal candidiasis. She was first tested and found to be positive for HIV-1 antibodies at 12 mo of age. Over the next year, she was frequently hospitalized for complications of interstitial pneumonitis, chronic diarrhea, and Hemophilus influenzae otitis media. She was treated with i.v. gamma globulin at a dose of $400 \mathrm{mg} / \mathrm{kg}$ every month. She had severe developmental delay, cortical blindness, and atropy. She died at 20 mo of age from the complications of a viral pneumonia.

Patient III was a male, prematurely delivered at $29 \mathrm{wk}$ of gestation as a result of an incompetent cervix. He developed respiratory distress after vaginal delivery. His neonatal course was complicated by mild hyaline membrane disease with right upper lobe collapse, bronchopulmonary dysplasia, right subependymal hemorrhage, intraventricular hemorrhage, apnea, bradycardia, and anemia that required blood transfusion. At 35 $\mathrm{d}$ of life, neutropenia and thrombocytopenia developed, which resolved spontaneously after 3 mo. Failure to thrive, lymphadenopathy, and hepatosplenomegaly were noted at 7 mo of age. He subsequently developed pneumococcal meningitis and was treated with i.v. Ig $400 \mathrm{mg} / \mathrm{kg}$ every month. He was first tested and found to be positive for HIV-1 antibodies at 12 mo of age. He had multiple hospital admissions for evaluation of possible sepsis, chronic diarrhea, and recurrent scabies. Gastroenteritis was associated with repeated culture of Aeromonas hydrophilia from his stools. The patient manifested developmental delay and regression as well as cerebral atrophy and frontal lobe and basal ganglia calcifications. His clinical course was marked by multiple infections. He was treated with azidothymidine but died at 31 mo of age.

Patient IV, a $940-\mathrm{g}$ female, was the product of a 27 -wk gestation. Pregnancy was complicated by chronic hypertension and preterm labor. The infant developed respiratory distress immediately after vaginal delivery. The neonatal course was complicated hy severe hyaline membrane disease progressing to bronchopulmonary dysplasia, grade II intraventricular hemorrhage, recurrent apnea, and retinopathy. She received multiple blood transfusions. After discharge at $95 \mathrm{~d}$ of age, she did not gain weight and was seen frequently in the emergency room for otitis and cough. On these occasions, extensive oral candidiasis was noted. Candida skin tests and lymphocyte proliferation responses to Candida were negative. At 9 mo of age, she was admitted to the hospital in a marasmic state with a history of chronic diarrhea. Though HIV-1 antibodies were not examined, HIV-1 p24 antigen was found to be positive. Severe cerebral atrophy was diagnosed by computed tomography scan. The patient died at 9 mo of age of a cardiorespiratory arrest.

Patient V, a male, was the 730-g product of a 27 -wk gestation complicated by severe preeclampsia. The patient was delivered by cesarean section. The patient's neonatal course was complicated by moderate hyaline membrane disease and bronchopulmonary dysplasia requiring intubation. He underwent a patent ductus arteriosis ligation and was evaluated on numerous occasions for sepsis. He exhibited bone demineralization and stage II retinopathy. He was discharged from the hospital at 4 mo of age but was readmitted for complications of recurrent viral infections, including respiratory distress and one prolonged tonicclonic seizure. Growth and speech milestones have been delayed, but development has otherwise been normal. There were no cerebral atrophy or intracranial calcifications detected by computed tomography scan. Since $8 \mathrm{mo}$ of age, he has had only occasional episodes of otitis media and no other serious infections. He has been treated with intramuscular $100 \mathrm{mg} / \mathrm{kg}$ gamma globulin/mo, and has remained well for more than $7.5 \mathrm{y}$ after HIV-1 infection.

Informed consent. Informed consent was obtained from all patients (or parents or guardians) who participated in this study. Human experimentation guidelines of the US Department of Health and Human Services and of Washington University School of Medicine Institutional Review Board were followed in the conduct of the clinical research.

\section{MATERIALS AND METHODS}

Virus isolation was performed by cocultivation of PBMC from the patient with an equivalent number of phytohemagglutininactivated PBMC from an uninfected donor (20). Cultures were grown for 12 wk in RPMI 1640 medium supplemented with $15 \%$ FCS, $5 \%$ IL-2, 2 mM glutamine, 100 units $/ \mathrm{mL}$ penicillin, and $100 \mu \mathrm{g} / \mathrm{mL}$ streptomycin. An equal number of fresh phytohemagglutinin-activated PBMC from an uninfected donor were added weekly.

Uncultured PBMC and cultured cells were washed in PBS and suspended in $100 \mu \mathrm{L}$ PBS, followed by the addition of $500 \mu \mathrm{L}$ of lysis buffer (1\% SDS, 1\% 2-mercaptoethanol, $10 \mathrm{mM}$ Tris-Cl, $\mathrm{pH} 8.0,150 \mathrm{mM} \mathrm{NaCl}$, and $5 \mathrm{mM}$ EDTA). Proteinase $\mathrm{K}$ was added to a concentration of $300 \mu \mathrm{g} / \mathrm{mL}$, and the cell lysate was incubated at $37^{\circ} \mathrm{C}$ for $60 \mathrm{~min}$. DNA was extracted with phenol and chloroform and precipitated with ethanol.

The first round of nested PCR was performed on $0.5 \mu \mathrm{g}$ of DNA in $50 \mathrm{mM} \mathrm{KCl} ; 10 \mathrm{mM}$ Tris-Cl, pH 8.3; $7 \mathrm{mM} \mathrm{MgCl}$; $400 \mu \mathrm{M}$ of each deoxyribonucleotide triphosphate; and 2.5 units of thermostable Taq DNA polyermase (Perkin-Elmer Cetus, Norwalk, CT). The inital round of PCR used envelope primers JA9Eco (nucleotides 7137-7156) (5) and JA12Eco (7572-7533) (21). PCR was performed in a Perkin-Elmer Cetus thermocycler programmed for 24 repeated cycles of target DNA thermal denaturation at $95^{\circ} \mathrm{C}$ for $30 \mathrm{~s}$, oligonucleotide primer annealing at $50^{\circ} \mathrm{C}$ for $30 \mathrm{~s}$, and Taq DNA polymerase-catalyzed template extension at $75^{\circ} \mathrm{C}$ for $30 \mathrm{~s}$ plus an additional $2 / \mathrm{s}$ cycle. One and a half $\mathrm{mL}$ of the first-round amplified DNA product were transferred to the second round of PCR, which was performed with envelope primers JA10Eco (nucleotides 7191-7210) and JA1 1Eco (nucleotides 7532-7513) with the identical conditions used in the first round of PCR but with only $4 \mathrm{mM} \mathrm{MgCl} 2$. All primers were 31 mers with 20 bases of sequences capable of annealing with HIV-1 sequences (21) and 11 bases containing an EcoRI site. The predicted error rate for PCR under these conditions is $<0.05 \%$ (22).

The expected 341-bp fragment was digested with EcoRI and cloned into the EcoRI site on pUC 19 using standard techniques (23). Dideoxynucleotide sequencing (24) was performed using Sequenase version 2.0 (United States Biochemical Corp., Cleveland, $\mathrm{OH}$ ) according to the manufacturer's recommendations, and complete sequences were obtained from both strands of each plasmid. All sequence numbers except those noted above for PCR primers were in accordance with a previous study (1). Sequences were submitted to Genbank as accession no. L06256L06273.

\section{RESULTS}

The current study involved the transfusion of a single unit of HIV-1-infected blood from an asymptomatic adult to six premature infants (Fig. 1). The transfusion occurred in January, 


\begin{tabular}{|c|c|c|c|c|c|c|}
\hline 1985 & 1986 & 1987 & 1988 & 1989 & 1990 & 1991 \\
\hline 1 & 1 & 2 & 3 & 4 & 5 & 6 \\
\hline
\end{tabular}

Transfusion Donor

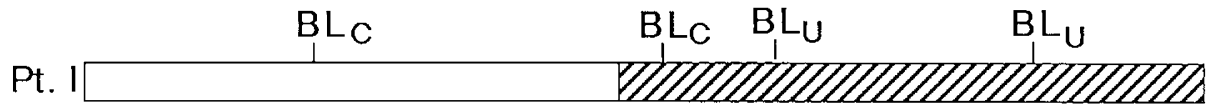

Transfusion Recipients

Pt. II

Pt. III $\square$

Pt. IV QI

Pt. V

Asymptomatic

Progressive Generalized Lymphadenopathy (PGL)

Q AIDS Related Complex (ARC)

AIDS

Fig. 1. Sources of HIV-1 isolates. Patient (Pt.) I, the transfusion donor, an adult from a high-risk population, was asymptomatic at the time of transfusion but developed symptoms of AIDS-related complex 3.4 y later Patients II, III, IV, and V were the premature infants who received equal portions of the same unit of blood. The associated clinical classifications of each patient are shown. Patient V, unlike the other pediatric patients, has remained asymptomatic during the 7 y since the transfusion. HIV-1 isolates were obtained from blood $(B L)$ at the indicated times from four of the patients. $B L_{U}$ indicates the time at which uncultured leukocytes were obtained for PCR. $B L_{C}$ indicates the time at which 90 -d cultured leukocytes were obtained for PCR.

1985, before the availability of HIV-1 serologic assays. The transfusion donor, patient I, developed HIV-1-related symptoms $3.4 \mathrm{y}$ after the transfusion. Four of the six pediatric patients were found to be HIV-1 infected. No other risk factors for HIV-1 infection were identified among the children or their mothers. No information about HIV-1 status is available for the other two pediatric patients who died of complications of their premature deliveries and for whom no tissues were preserved for HIV-1 status.

Three of the four HIV-1-infected pediatric patients, patients II, III, and IV, developed symptomatic HIV-1 disease and died of complications of AIDS within the first 3 y of life. In contrast, the fourth HIV-1-infected child, patient V, has remained asymptomatic for more than $7 \mathrm{y}$ since acquiring HIV-1 infection.

Viremia was noted in patients II, III, and IV at all determinations of p24 antigen (Fig. 2). In contrast, p24 antigen was undetectable at all times in patient V. Though HIV-1 was cultured from the blood of patient $\mathrm{V}$ at 1.0, 5.4, and $5.7 \mathrm{y}$ of age, six other cultures between 1.0 and 5.4 y of age were negative (Fig. 1 and data not shown). In contrast, all culture attempts from patients II and III yielded infectious virus as measured by reverse transcriptase or p24 antigen assays.

Declining CD4:CD8 ratios were noted for patients II and III, and patient IV had a low CD4:CD8 value at the only determination (Fig. 2). In contrast, CD4:CD8 ratios consistently ranged between 1.0 and 1.5 over the first 48 mo of life for patient $\mathrm{V}$, then subsequently declined to 0.5 . Ig levels, reflecting $\mathrm{B}$ cell activation (26), were elevated in both patients II and III initially, but were slightly below the normal range for patient $\mathrm{V}$.

A previous study reported the nucleotide sequences for the entire env gene of cultured isolates from patients I, II, and III (1). This included 13 clones from seven isolates derived from blood, lung, and brain tissues. No differences were noted in the region containing the V3 principal neutralizing loop, nucleotides 794-1083. In the current study, nucleotide sequences obtained from HIV-1 isolates of patient V, whose clinical course differed significantly from those of patients II and III, were compared with the sequences obtained from HIV-1 isolates of patients II and III. For this purpose, PCR was used to amplify distinct sequences from HIV-1 quasispecies present in a cultured isolate obtained from patient $\mathrm{V}$ at $5.4 \mathrm{y}$ of age and from uncultured peripheral blood leukocytes obtained at 4.0 and $6.3 \mathrm{y}$ of age. Additionally, sequences were determined for clones from uncultured peripheral blood leukocytes of the blood donor, patient I, obtained in July 1989 and September 1991.

Six clones were sequenced from PCR products of uncultured leukocytes of patient V obtained in February 1989 (4.0 y of age; clones VU 11-VU 16), and these clones exhibited sequences identical to each other and to that of clone IC 1, derived from a cultured isolate in June 1986 (Fig. 3). Seven clones were sequenced from PCR products of the uncultured leukocytes (VU 1-VU 7) obtained in April 1991 (6.3 y of age), and five unique sequences were obtained. Amino acid substitutions, deletions, and insertions relative to each other and to corresponding se- 


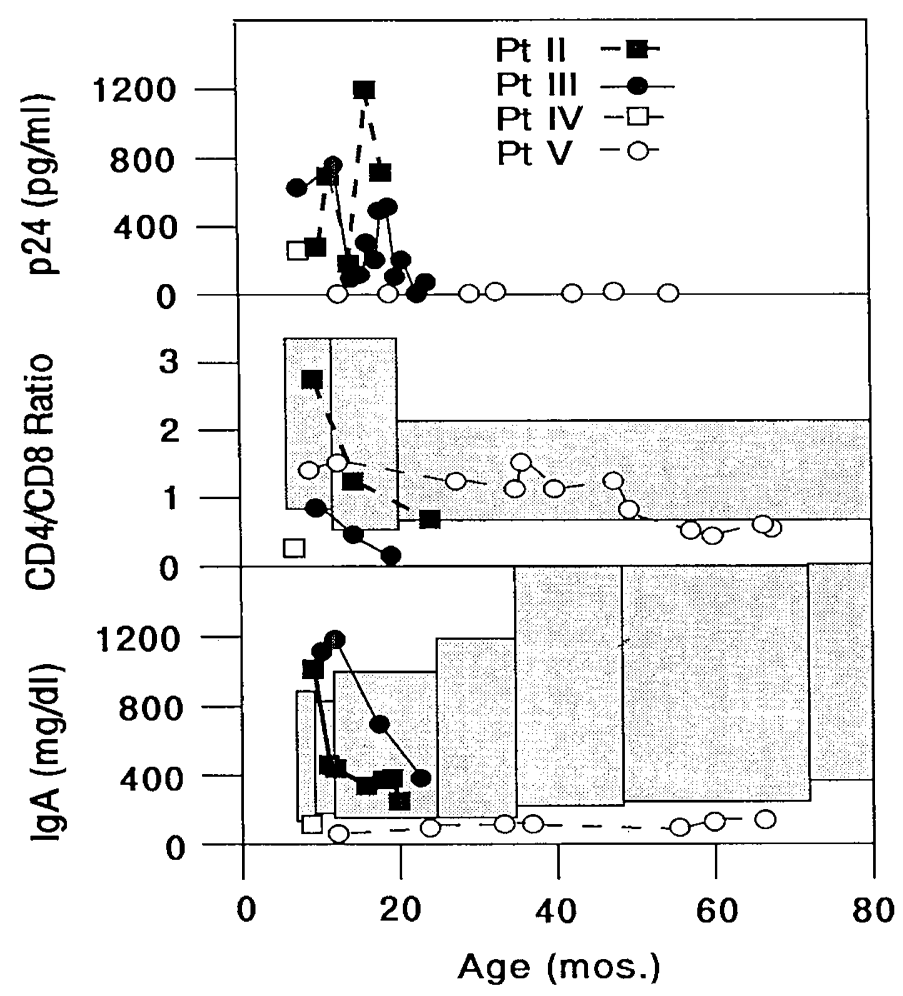

Fig. 2. Virologic and immunologic parameters of the cohort in the transfusion study. The figure shows serum p24 antigen results, CD4:CD8 ratios, and $\operatorname{IgA}$ levels for the pediatric patients according to respective ages. Boxes for CD4:CD8 ratios and IgA levels indicate 5th to 95th percentile range of normal age-corrected values (25). Similar findings were found for $\mathrm{IgG}$ levels.

quences of a cultured isolate and earlier uncultured isolates derived from both patients are shown in Figure 3.

Six clones were sequenced from PCR products of the cultured isolate (VC 2, VC 3, VC 5, VC 6, VC 7, and VC 8; Fig. 3). Four of these sequences were unique with respect to each other and with respect to other available HIV-1 sequences.

Five clones were sequenced from PCR products of uncultured leukocytes of patient I obtained in July 1989 (IU 8-IU 12), and these clones exhibited sequences identical to each other and to that of clone IC 1 (Fig. 3). Seven clones were sequenced from PCR products of uncultured leukocytes of patient I obtained in September 1991 (IU 22, 23, 27, 28, 30, 31, 32, 33), and the positions of amino acid alterations are indicated. Also included for comparison in Figure 3 are the sequences of representative isolates from North American or European patients, WMJ2 and $\mathrm{HXB} 2$, and a representative isolate from an African patient, ELI (3).

Analysis of the V3 region included both interperiod and intraperiod sequences for cultured and uncultured isolates over a 5-y period. The sequence divergence was greatest in the uncultured isolates from late time points. In the isolates derived from uncultured leukocytes obtained in 1989 from both patients I and $\mathrm{V}$, identical predicted amino acid sequences were found in comparison to those of earlier cultured isolates of patients I, II, and III. However, in the uncultured 1991 samples, both patients displayed marked heterogeneity. Intraperiod divergences for isolates from late time points from patients I and V were 2.1-16.6 and $0-13.5 \%$, respectively (Table 1 ). Comparisons of the same late time-point isolates to the early time-point isolates showed 14.5-19.8 and 6.3-16.6\% differences, respectively. Analysis of late time-point isolates with respect to the earlier isolates revealed 30 amino acid substitutions over 96 positions for patient I and 25 substitutions for patient $\mathrm{V}$. Of these mutations, $50 \%$ are shared with respect to amino acid positions. In spite of the similarities noted in these two patients, who have experienced a relatively benign infectious course thus far, both patients also demonstrate unique sequence alterations.

Higher levels of amino acid divergence $(21.8-27.1 \%)$ were noted in comparison to other representative North American or European isolates, WMJ2 and HXB2 (Table 1). In comparisons of sequences from isolates of patients I and V to the African isolate, ELI, a sequence divergence of $48 \%$ was noted for early time points and ranges of $41.0-47.9 \%$ and $43.0-44.8 \%$, respectively, for the 1991 uncultured isolates.

Analysis of the V3 loops in these isolates demonstrated that the isolates derived from 1989 samples differed from the North American consensus sequence (27) at three amino acid positions, which expands to a range of three to seven amino acid substitutions in the late time-point isolates in patient I and two to five amino acid substitutions in patient $\mathrm{V}$.

Cysteine residues flanking the V 3 immunodominant loop are conserved in all isolates. Furthermore, the V3 loop is 35 amino acids long in all isolates. In HXB2, it is 36 amino acids long, and in WMJ2 and ELI it is 34 amino acids long. Two potential

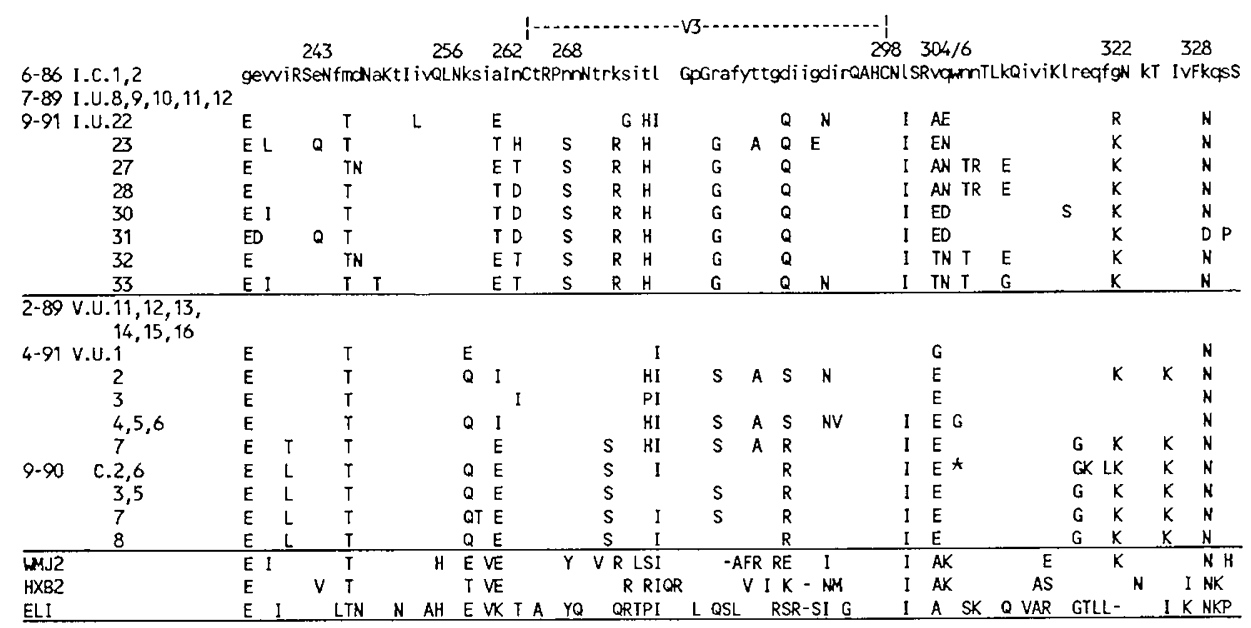

Fig. 3. Amino acid sequence comparisons of HIV-1 isolates. Predicted amino acid sequences for residues 235-333 of envelope are shown for clone IC 1 , and differences are indicated for each of the other isolates listed below. Amino acids listed in lower case letters for clone IC 1 indicate positions for which differences exist in other clones. Above the sequences, the V3 loop region is indicted. The $\star$ indicates a termination codon present in clone VC 2 and VC 6. Numbers above the sequence for IC 1 indicate potentiai N-glycosylation sites. Dashes indicate deletions relative to clone (IC 1). 


\begin{tabular}{|c|c|c|c|c|c|c|c|c|c|}
\hline & I.C. 1 & I.U. $8-12$ & $\begin{array}{r}\text { I.U. } 22,23 \\
27,28,30 \\
31,32,33 \\
\end{array}$ & V.U.11-16 & V.U.1-7 & V.C. $2-8$ & WMJ2 & HXB2 & ELI \\
\hline I.C. 1 & 0 & 0 & $14.5-19.8$ & 0 & $6.3-16.6$ & $14.5-17.8$ & 27.1 & 22.9 & 47.9 \\
\hline I.U. $8-12$ & & 0 & $14.5-19.8$ & 0 & $6.3-16.6$ & $14.5-17.8$ & 27.1 & 22.9 & 47.9 \\
\hline $\begin{array}{l}\text { I.U. } 22,23 \\
27,28,30\end{array}$ & & & $2.1-16.6$ & $14.5-19.8$ & $11.5-19.8$ & $13.5-21.1$ & $21.8-25.0$ & $18.8-27.0$ & $41.0-47.9$ \\
\hline $\begin{array}{r}31,32,33 \\
\end{array}$ & & & & 0 & & & & & \\
\hline $\begin{array}{l}\text { V.U.11-16 } \\
\text { V.U.1-7 }\end{array}$ & & & & 0 & $\begin{array}{r}0.3-16.6 \\
0-135\end{array}$ & $\begin{array}{r}14.3-11.8 \\
42-146\end{array}$ & $\begin{array}{c}27.1 \\
218-250\end{array}$ & $\begin{array}{c}22.9 \\
208-250\end{array}$ & $\begin{array}{c}48.0 \\
430-448\end{array}$ \\
\hline V.C. $2-8$ & & & & & & $0-5.2$ & $23.0-26.5$ & $22.9-26.0$ & $44.0-45.8$ \\
\hline WMJ2 & & & & & & & & 26.0 & 40.6 \\
\hline HXB2 & & & & & & & & & 45.8 \\
\hline
\end{tabular}

$\mathrm{N}$-glycosylation sites at residues 298 and 322 are conserved in all isolates. Six additional potential $\mathrm{N}$-glycosylation sites are present between amino acid residues 235, and 331 are found in some isolates. HIV-1 sequences from patient I demonstrated a conservation of the $\mathrm{N}$-glycosylation site at position 306, but evolving sequences demonstrated a shift in position by two amino acids for the $\mathrm{N}$-glycosylation site to position 304 . Also of note is the termination codon at position 305 in clones VC 2 and VC 6. Differences in predicted amino acid sequences among isolates from patients $\mathrm{V}$ and $\mathrm{I}$ and those from representative North American and African isolates are also noted in Figure 3.

The V3 loop is predicted to be located between disulfide bonded cysteine residues 263 and 297. The frequency of residues near the tip of the loop has been determined in a previous study examining 245 sequences from diverse HIV-1 isolates (27), and the frequency for which each amino acid is found at that particular position is indicated. Three residues in the V3 loop, proline at position 278 , tyrosine at position 283 , and aspartic acid at position 287 , have been implicated in regulation of cell tropism of HIV-1 for monocytes or primary glial cultures $(28,29)$. The tyrosine has also been shown to regulate cytotoxic T-cell responses to the HIV-1 envelope (17). A cleavage site for thrombin, tryptase, and an endogenous Chinese hamster ovary cell protease is found between arginine 280 and alanine 281 (12-14).

Amino acid sequence differences within the $\mathrm{V} 3$ loop are noted at eight different positions among the clones from patient $\mathrm{V}$ (April 1991) and 10 positions among clones from patient I (September 1991) compared with the clones from earlier time points and among clones from patients II and III. Three of these changes are unusual compared with previously described V3 loop sequences: a serine for arginine 271 , a proline for threonine 275 , and a serine for arginine 280 . Leucine 276 in IC 1 , an unusual amino acid at this position, is replaced by isoleucine in eight of 19 clones from patient $\mathrm{V}$. This amino acid residue is found in $82 \%$ of other V3 loop sequences. The substitution of arginine for aspartic acid 287 may affect HIV-1 tropism for monocytes (Henkel T, Westervelt P, Carrillo A, Trowbridge DB, Ratner L, unpublished observations).

\section{DISCUSSION}

This study offers a unique opportunity to study related isolates with respect to temporal, clinical, and genetic progression of HIV-1 sequences.

Transmission of HIV-1 by blood transfusion accounts for $2.6 \%$ of HIV-1 infections and $11.1 \%$ of pediatric HIV-1 cases $(30,31)$. In the cohort examined here, all four children who shared the same unit of HIV-1-contaminated blood and for whom tissues were available were found to be HIV-1 infected. The high rate of acquisition of HIV-1 by transfusion has been noted in previous studies $(32,33)$.

The indolent clinical course of patient $\mathrm{V}$ is clearly distinct from the rapidly symptomatic and fatal HIV-1 disease manifested in patients II and III. Although plasma virus cultures were not performed in this study, it is likely that the virus load was significantly lower in patient V than patients II and III. Only three of 10 lymphoblastoid cultures from patient $\mathrm{V}$ were positive, whereas all virus cultures of samples from patients II and III yielded infectious virus. Furthermore, serum p24 antigen levels were undetectable in patient $\mathrm{V}$ but elevated in patients II and III at all determinations (Fig. 2).

The laboratory evidence of gradual immunologic deterioration in patient $\mathrm{V}$ is contrasted with the rapid deterioration seen in patients II and III (Fig. 2). This is manifested by quantitative studies of the CD4+ lymphocyte population as well as an examination of polyclonal B cell activation as measured by serum Ig levels. Both of these parameters have been reported to be important prognostic markers for progression of HIV-1 disease in children (26).

The range of clinical sequelae of HIV-1 infection identified in this cohort reflects the wide range of disease manifestations seen in other infected pediatric populations. It is unlikely that quantitative or qualitative differences in the virus inoculum account for the marked differences in clinical sequelae, inasmuch as similar amounts of contaminated blood were used for transfusion of each of the neonates. Furthermore, the range of viral species in the donated blood was quite restricted (1). Therefore, the current study examined the range of viral quasispecies present in patient $\mathrm{V}$ (and the blood donor, patient $\mathrm{I}$ ), focusing on the $\mathrm{V} 3$ immunodominant loop to assess a region known to interact with the host cell and possibly affect infectivity by changes in sequence during disease evolution.

HIV-1 sequences were cloned from both virus cultured in primary lymphocytes and uncultured leukocytes. Previous studies have suggested that $\mathrm{CD} 4+$ lymphocytes are the predominantly infected cell type in blood of infected patients (34). Thus, the cellular source of viral sequences was likely similar in each case. However, it is notable that the level of sequence diversity obtained from cultured virus was more restricted than that obtained from uncultured cells (Table 1). Similar findings have been reported by other investigators examining other portions of the HIV-1 genome $(22,35)$. Lymphoblastoid cultures may bias the population of examined HIV-1 strains by selecting for those that manifest the highest level of replication in vitro. It is also evident that identical sequences can be obtained from both cultured and uncultured species. The quasispecies in the cultured isolate are not necessarily the strains most relevant to disease pathogenesis in vivo. Sequences obtained from uncultured material more appropriately reflect the range of quasispecies present in vivo.

However, either of these methods may yield defective clones of the virus. In this regard, it is noteworthy that a termination codon is present in two of the clones from the cultured isolates (Fig. 3). Presumably, these were propagated in vitro or in vivo as a result of complementation by coexisting strains expressing a functional envelope protein. Termination codons in the transmembrane envelope protein were identified in all of the clones obtained from cultured isolates from patients I to III (1). The 
coexistence of defective and nondefective strains of HIV-1 in uncultured brain tissue has recently been demonstrated by Li et al. (36).

Sequences obtained from HIV-1 quasispecies from patient V are different from those previously reported from patients II and III. These clearly represent independent isolates of the virus. However, isolates from patients I and $\mathrm{V}$ are more closely related to one another $(0-21.1 \%$ amino acid differences) than to other North American and European strains (18.8-27.1\% amino acid differences, Table 1). The African isolate, ELI, manifests an even greater level of sequence divergence from any of these North American or European strains (41.0-48.0\% amino acid differences).

Several other recently published studies have examined V3 envelope variation among individuals in a clustered infectious outbreak. Burger et al. (37) reported 3.7-8.5\% nucleotide sequence variation in the entire env gene of the predominant clones of a woman who transmitted HIV-1 heterosexually to her partner and vertically to her daughter. Wolfs et al. (38) noted nucleotide sequence variation in the portion of env encoding V3 of $0.3-$ $11.4 \%$ among six children and the adult donor whose plasma was the source of the pediatric infectious outbreak (38). Balfe et al. (39) reported variation of $3.2-21.8 \%$ of nucleotides in a portion of env encoding V3 among six hemophiliacs exposed to a common batch of VIII (39). In contrast, Cichutek et al. (40) noted identical V3 sequences in 10 of 12 clones from two hemophiliacs who acquired HIV-1 infection from a common batch of clotting factors. Although the range of nucleotide sequence variation in the current clustered infectious outbreak among patients I, II, and III is similar to that described by Cichutek et al., the sequence differences between patient $\mathrm{V}$ and patients I, II, and III (0-6.9\% nucleotide sequence differences) are comparable to the forementioned studies.

In comparisons of the predicted V3 loop amino acid sequences of late time-point isolates with those from patients I-III, 10 of 35 positions of isolates from patient I and eight of 35 positions of isolates from patient $\mathrm{V}$ are altered (Fig. 3). In both of the patients, one of these changes leads to a substitution of glycine 280 or serine 280 for an arginine at a proteolytic cleavage site. Cleavage has been demonstrated at this site with thrombin, tryptase TL2, and a Chinese hamster ovary cell protease (12-14). Cleavage may be enhanced by addition of soluble CD4, suggesting that receptor binding may lead to a conformational change that exposes the cleavage site. Though it has been suggested that V3 loop cleavage is important for virus infectivity, direct evidence supporting this hypothesis has remained elusive. The serine substitution would be predicted to eliminate cleavage susceptibility, but this remains to be confirmed in functional studies.

A second alteration in the V3 loop of late time-point isolates of patients I and V compared with patients I-III is the substitution of glutamine or arginine for an aspartic acid at position 287 . A similar basic for acidic amino acid alteration has been shown in studies with other HIV-1 isolates to convert a monocyte-tropic isolate of HIV-1 to a nonmonocyte-tropic strain (Henkel $\mathrm{T}$, Westervelt P, Carrillo A, Trowbridge DB, Ratner L, unpublished observations). It remains to be proven that this residue has a similar role in the context of the sequences present in the V3 loop of the isolates from these patients. However, it is possible that a change in tissue tropism of HIV-1 quasispecies may have been at least partially responsible for the differences in disease course seen among these patients. It is interesting that both positions are altered in both late time-point isolates.

Lastly, the V3 loop is the predominant target for type-specific neutralizing antibodies (16). Primary sequence substitutions have been shown to alter virus neutralization. Studies of neutralization susceptibility of viral strains with V3 sequences from patients II and $\mathrm{V}$ with sera from each of these patients may also shed light on the possible contribution to disease pathogenesis of such V3 loop sequence alterations.
Acknowledgment. The authors thank Dave Starkey for technical assistance.

\section{REFERENCES}

1. McNearney T, Westervelt P, Thielan BJ, Trowbridge DB, Whittier R, Ratner L 1990 Limited sequence heterogeneity among biologically distinct human immunodeficiency virus type 1 isolates from individuals involved in a clustered infectious outbreak. Proc Natl Acad Sci USA 87:1917-1921

2. Katz RA, Skalka AM 1990 Generation of diversity in retroviruses Annu Rev Genet 24:409-415

3. Myers G, Berzofsky JA, Korber B, Smith RF, Pavlakis GN 1991 Human retroviruses and AIDS, 1991. Los Alamos National Laboratory, Los Alamos, NM

4. Hahn BH, Shaw GM, Taylor ME, Redfield RR, Markham PD, Salahuddin SZ, Wong-Staal F, Gallo RC, Parks ES, Parks WP 1986 Genetic variation in HTLV-III/LAV over time in patients with AIDS or at risk for AIDS. Science 232:1548-1553

5. Ratner L, Haseltine W, Patarca R, Livak KJ, Starcich B, Josephs SF, Doran ER, Rafalski JA, Whitehorn EA, Baumeister K, Ivanoff L, Petteway SR, Pearson ML, Lautenberger JA, Papas TS, Ghrayeb J, Chang NT, Gallo RC, Wong-Staal F 1985 Complete nucleotide sequence of the AIDS virus, HTLVIII. Nature 313:277-284

6. Alizon M, Wain-Hobson S, Montagnier L, Sonigo P 1986 Genetic variability of the AIDS virus: nucleotide sequence analysis of two isolates from African patients. Cell 46:63-74

7. Modrow S, Hahn BH, Shaw GM, Gallo RC, Wong-Staal F, Wolf H 1987 Computer-assisted analysis of envelope protein sequences of seven human immunodeficiency virus isolates: prediction of antigenic epitopes in conserved and variable regions. J Virol 61:570-578

8. Leonard CK, Spellman MW, Riddle L, Harris RJ, Thomas JN, Gregory TJ 1990 Assignment of intrachain disulfide bonds and characterization of potential glycosylation sites of the type 1 recombinant human immunodeficiency virus envelope glycoprotein (gp120) expressed in Chinese hamster ovary cells. J Biol Chem 265:10 373-10 382

9. Willey RL, Ross EK, Buckler-White AJ, Theodore TS, Martin MA 1989 Functional interactions of constant and variable domains of human immunodeficiency virus type $1 \mathrm{gp} 120$. J Virol 63:3595-3600

10. Ivanoff L, Looney D, McDanal C, Morris JF, Wong-Staal F, Langlois AJ Petteway SR, Matthews TJ 1991 Alteration of HIV-1 infectivity and neutralization by a single amino acid replacement in the V3 loop domain. AIDS Res Hum Retrovir 7:595-604

11. Freed E, Myers D, Risser R 1991 Identification of the principal neutralizing determinant of human immunodeficiency virus type 1 as a fusion domain. J Virol 65:190-194

12. Clements GJ, Price-Jones MJ, Stephens PE, Sutton C, Schulz TF, Clapham PR, McKeating JA, McClure MO, Thomson S, Marsh M, Kay J, Weiss RA, Moore JP 1991 The V3 loops of the HIV-1 and HIV-2 surface glycoproteins contain proteolytic cleavage sites: a possible function in viral fusion? AIDS Res Hum Retrovir 7:3-16

13. Kido H, Fukutomi A, Katunuma N 1990 A novel membrane-bound serine esterase in human $\mathrm{T} 4+$ lymphocytes immunologically reactive with antibody inhibiting syncytia induced by HIV-1. Purification and characterization. J Biol Chem 265:21 979-21 985

14. Stephens PE, Clements G, Yarranton GT, Moore JP 1990 A chink in HIV's armour? Nature 243:219

15. Olshevsky U, Helseth E, Furman W, Haseltime W, Sodroski J 1990 Identification of individual human immunodeficiency virus type 1 gp 120 amino acids important for CD4 receptor binding. J Virol 64:5701-5707

16. Javaherian K, Langlois AJ, LaRosa GJ, Profy AT, Bolognesi DP, Herlihy WC Putney SD, Matthews TJ 1990 Broadly neutralizing antibodies elicited by hypervariable neutralizing determinant of HIV-1. Science 250:1590-1593

17. Takahashi H, Merli S, Putney SD, Houghten R, Moss B, Germain RN, Berzofsky JA 1989 A single amino acid interchange yields reciprocal CTL specificities for HIV-1 gp 160. Science 246:118-121

18. Ho DD, McKeating JA, Li XL, Moudgil T, Daar ES, Sun NC, Robinson JE 1991 Conformational epitope on gp120 important in CD4 binding and human immunodeficiency virus type 1 neutralization identified by a human monoclonal antibody. J Virol 65:489-493

19. Gorny MK, Xu JY, Gianakakos V, Karwowska S, Williams C, Sheppard HW, Hanson CV, Zolla-Pazner S 1991 Production of site-selected neutralizing human monoclonal antibodies against the third variable domain of the human immunodeficiency virus type 1 envelope glycoprotein. Proc Nat Acad Sci USA 88:3238-3242

20. Jackson JB, Kwok SY, Sninsky JJ, Hopsicker JS, Sannerud KJ, Rhame FS Henry K, Simpson M, Balfour HH 1990 Human immunodeficiency virus type 1 detected in all seropositive symptomatic and asymptomatic individuals. J Clin Microbiol 28:16-19

21. Albert J, Fenyo EM 1990 Simple, sensitive, and specific detection of human immunodeficiency virus type 1 in clinical specimens by polymerase chain reaction with nested primers. J Clin Microbiol 28:1560-1564

22. Delassus S, Cheynier R, Wain-Hobson S 1991 Evolution of human immunodeficiency virus type 1 nef and long terminal repeat sequences over 4 years in vivo and in vitro. $\mathrm{J}$ Virol $65: 225-231$

23. Maniatis T, Fritsch EF, Sambrook J 1982 Molecular Cloning: A Laboratory Manual, Cold Spring Harbor Laboratory, Cold Spring Harbor, NY

24. Sanger F, Nicklen S, Coulson AR 1977 DNA sequencing with chain-terminating inhibitors. Proc Natl Acad Sci USA 74:5463-5467 
25. Denny TN, Niven P, Skuza C, Chadwick EG, Kriger L, Amer M, Connor EM, Oleske JM, Yogev R 1990 Age-related changes of lymphocyte phenotypes in healthy children. Pediatr Res 27:155A(abstr 916)

26. Lane HC, Fauci AS 1985 Immunologic abnormalities in the acquired immunodeficiency syndrome. Annu Rev Immunol 3:477-500

27. LaRosa GJ, Davide JP, Weinhold K, Waterbury JA, Profy AT, Lewis JA, Langlois AJ, Dreesman GR, Boswell RN, Shadduck P, Holley CH, Karplus M, Bolognesi DP, Matthews TJ, Emini EA, Putney SD 1990 Conserved sequence and structural elements in the HIV-1 principal neutralizing determinant. Science 249:932-935

28. Takeuchi X, Akutsu M, Murayama K, Shimizu N, Hoshino H 1991 Host range mutant of human immunodeficiency virus type 1: modification of cell tropism by a single point mutation at the neutralization epitope in the env gene. J Virol 65:1710-1718

29. Westervelt P, Gendelman HE, Ratner L 1991 Identification of a determinant within the HIV-1 surface envelope glycoprotein critical for productive infection of cultured primary monocytes. Proc Natl Acad Sci USA 188: 3097-3101

30. Haverkos HW 1987 Epidemiology of AIDS in hemophiliacs and blood transfusion recipients. Antibiot Chemother 38:59-65

31. 1990 Update: acquired immunodeficiency disease syndrome-United States 1989. MMWR 39:81

32. Donegan E, Marla S, Niland JC 1990 Infection with human immunodeficiency virus type 1 (HIV-1) among recipients of antibody-positive blood donations. Ann Intern Med 113:733-738

33. Anderson KC, Gorgone BC, Marlick RG, Ferriani R, Essex ME, Benz PM,
Groopman JE 1986 Transfusion-acquired human immunodeficiency virus infection among compromised persons. Ann Intern Med 105:519-527

34. Schnittman SM, Psallidopoulos MD, Lane HC, Thompson L, Baseler M, Massari F, Fox CH, Salzman NP, Fauci AS 1989 The reservoir for HIV-1 in human peripheral blood is a T-cell that maintains expression of CD4. Science 225:59-63

35. Meyerhans A, Cheynier R, Albert J, Seth M, Kwok S, Sninsky J, MorfeldtManson L, Asjo B, Wain-Hobson S 1989 Temporal fluctuations in HIV quasispecies in vivo are not reflected by sequential HIV isolations. Cell 58: 901-910

36. Li Y, Happes JC, Conway JA, Price RW, Shaw GM, Hahn BH 1991 Molecular characterization of human immunodeficiency virus type 1 cloned directly from uncultured human brain tissue: identification of replication-competent and -defective viral genomes. J Virol 65:3973-3985

37. Burger H, Weiser B, Flahert K, Gulla J, Nguyen P-N, Gibbs RA 1991 Evolution of human immunodeficiency virus type 1 nucleotide sequence diversity among close contacts. Proc Natl Acad Sci USA 88:11 236-11 240

38. Wolfs TFW, de Jong J-J, Van den Berg H, Tijnagel JMGH, Krone WJA Goudsmit J 1990 Evolution of sequences encoding the principal neutralization epitope of human immunodeficiency virus 1 is host dependent, rapid, and continuous. Proc Natl Acad Sci USA 87:9938-9942

39. Balfe P, Simmonds P, Ludlam CA, Bishop JO, Brown AJL 1990 Concurrent evolution of human immunodeficiency virus type 1 in patients infected from the same source: rate of sequence change and low frequency of inactivating mutations. J Virol 64:6221-6233

40. Cichutek K, Norley S, Linde R, Kreuz W, Gahr M, Lower J, von Wangenheim G, Kurth R 1991 Lack of HIV-1 V3 region sequence diversity in two haemophiliac patients infected with a putative biological clone of HIV-1. AIDS 5:1185-1187

\section{Announcement}

\section{Annual Meeting of the Society for Adolescent Medicine}

The Society for Adolescent Medicine, a multidisciplinary professional organization, will hold its annual meeting March 18-21, 1992, at the Hilton Hotel, Chicago, IL. The theme of the meeting will be "Interfacing of Health and Education." In addition to addressing this topic, the meeting will present new material on a broad range of issues important to adolescent physical and emotional health, including AIDS and HIV medical management, teenage sexuality, eating disorders, depression, and risk taking behaviors such as drug and alcohol use and abuse. Meeting presentations include all-day institutes, scientific research paper presentations and poster sessions, as well as the prestigious Gallagher Lecture Series. CME/CEUs are available. For additional information, contact the Society for Adolescent Medicine, Suite 120, 19401 E. U.S. Highway 40, Independence, MO 64055, (816) $795-8336$. 
25. Denny TN, Niven P, Skuza C, Chadwick EG, Kriger L, Amer M, Connor EM, Oleske JM, Yogev R 1990 Age-related changes of lymphocyte phenotypes in healthy children. Pediatr Res 27:155A(abstr 916)

26. Lane HC, Fauci AS 1985 Immunologic abnormalities in the acquired immunodeficiency syndrome. Annu Rev Immunol 3:477-500

27. LaRosa GJ, Davide JP, Weinhold K, Waterbury JA, Profy AT, Lewis JA, Langlois AJ, Dreesman GR, Boswell RN, Shadduck P, Holley CH, Karplus M, Bolognesi DP, Matthews TJ, Emini EA, Putney SD 1990 Conserved sequence and structural elements in the HIV-1 principal neutralizing determinant. Science 249:932-935

28. Takeuchi Y, Akutsu M, Murayama K, Shimizu N, Hoshino H 1991 Hos range mutant of human immunodeficiency virus type 1: modification of cell tropism by a single point mutation at the neutralization epitope in the env gene. J Virol 65:1710-1718

29. Westervelt P, Gendelman HE, Ratner L 1991 Identification of a determinant within the HIV-1 surface envelope glycoprotein critical for productive infection of cultured primary monocytes. Proc Natl Acad Sci USA 188 3097-3101

30. Haverkos HW 1987 Epidemiology of AIDS in hemophiliacs and blood transfursion recipients. Antibiot Chemother 38:59-65

31. 1990 Update: acquired immunodeficiency disease syndrome-United States 1989. MMWR 39:81

32. Donegan E, Marla S, Niland JC 1990 Infection with human immunodeficiency virus type 1 (HIV-1) among recipients of antibody-positive blood donations. Ann Intern Med 113:733-738

33. Anderson KC, Gorgone BC, Marlick RG, Ferriani R, Essex ME, Benz PM,
Groopman JE 1986 Transfusion-acquired human immunodeficiency virus infection among compromised persons. Ann Intern Med 105:519-527

34. Schnittman SM, Psallidopoulos MD, Lane HC, Thompson L, Baseler M, Massari F, Fox CH, Salzman NP, Fauci AS 1989 The reservoir for HIV-1 in human peripheral blood is a T-cell that maintains expression of CD4. Science 225:59-63

35. Meyerhans A, Cheynier R, Albert J, Seth M, Kwok S, Sninsky J, MorfeldtManson L, Asjo B, Wain-Hobson S 1989 Temporal fluctuations in HIV quasispecies in vivo are not reflected by sequential HIV isolations. Cell 58: $901-910$

36. Li Y, Happes JC, Conway JA, Price RW, Shaw GM, Hahn BH 1991 Molecular characterization of human immunodeficiency virus type 1 cloned directly from uncultured human brain tissue: identification of replication-competent and -defective viral genomes. J Virol 65:3973-3985

37. Burger H, Weiser B, Flahert K, Gulla J, Nguyen P-N Gibbs RA 1991 Evolution of human immunodeficiency virus type 1 nucleotide sequence diversity among close contacts. Proc Natl Acad Sci USA 88:11 236-11 240

38. Wolfs TFW, de Jong J-J, Van den Berg H, Tijnagel JMGH, Krone WJA, Goudsmit J 1990 Evolution of sequences encoding the principal neutralization epitope of human immunodeficiency virus 1 is host dependent, rapid, and continuous. Proc Natl Acad Sci USA 87:9938-9942

39. Balfe P, Simmonds P, Ludlam CA, Bishop JO, Brown AJL 1990 Concurrent evolution of human immunodeficiency virus type 1 in patients infected from the same source: rate of sequence change and low frequency of inactivating mutations. J Virol 64:6221-6233

40. Cichutek K, Norley S, Linde R, Kreuz W, Gahr M, Lower J, von Wangenheim $G$, Kurth R 1991 Lack of HIV-1 V3 region sequence diversity in two haemophiliac patients infected with a putative biological clone of HIV-1. AIDS 5:1185-1187

\section{Announcement}

\section{Annual Meeting of the Society for Adolescent Medicine}

The Society for Adolescent Medicine, a multidisciplinary professional organization, will hold its annual meeting March 18-21, 1992, at the Hilton Hotel, Chicago, IL. The theme of the meeting will be "Interfacing of Health and Education." In addition to addressing this topic, the meeting will present new material on a broad range of issues important to adolescent physical and emotional health, including AIDS and HIV medical management, teenage sexuality, eating disorders, depression, and risk taking behaviors such as drug and alcohol use and abuse. Meeting presentations include all-day institutes, scientific research paper presentations and poster sessions, as well as the prestigious Gallagher Lecture Series. CME/CEUs are available. For additional information, contact the Society for Adolescent Medicine, Suite 120, 19401 E. U.S. Highway 40, Independence, MO 64055, (816) 795-8336. 